\section{(A) Check for updates}

Cite this: Dalton Trans., 2019, 48 9625

Received 11th February 2019,

Accepted 4th March 2019

DOI: $10.1039 / c 9 d t 00628 a$

rsc.li/dalton

\title{
Rhodium(I) complexes with carborane-substituted $P, N$ ligands: investigations of electronic structure and dynamic behaviour $\dagger$
}

\author{
Peter Coburger, (DD a Gizem Kahraman, (iD ${ }^{\text {a,b }}$ Axel Straube ${ }^{a}$ and \\ Evamarie Hey-Hawkins (iD *a
}

Two distorted square-planar $\mathrm{Rh}^{\prime}$ complexes ( $\mathbf{1}$ and 2$)$ were obtained from $\left[\left\{\mathrm{RhCl}\left(\eta^{4}-\mathrm{cod}\right)\right\}_{2}\right]$ and the respective $P, N$ ligands. The metal-ligand interaction was probed with density functional theory (DFT) and ab initio (CASSCF-NEVPT2) calculations. NMR spectroscopy proved dynamic binding behaviour of the ligands in solution. The tetradenticity of the ligands also affects the electrochemical behaviour of complexes 1 and $\mathbf{2}$ significantly. Finally, preliminary catalytic studies, namely the dehydrocoupling of dimethylamine-borane, are presented.

\section{Introduction}

In homogeneous catalysis, ligands, which combine soft and hard donor atoms, according to the HSAB principle, can act as hemilabile ligands and are, therefore, often superior to ligands with either hard or soft donor atoms. ${ }^{1}$ Often encountered are combinations of phosphorus with nitrogen or oxygen donor atoms. ${ }^{1 b, c}$ Alkyl and aryl groups have been predominantly used as substituents at phosphorus. In contrast, icosahedral carborane moieties have been rarely used as substituents in these ligands, despite their appealing properties. ${ }^{2}$ Especially the 1,2-dicarba-closo-dodecaborane (ortho-carborane) displays some properties which make it very attractive for ligand design such as a flexible $\mathrm{C}_{\text {cluster }}-\mathrm{C}_{\text {cluster }}$ bond, its electron-withdrawing effect, the possibility of the hydridic $\mathrm{B}-\mathrm{H}$ hydrogen atoms to participate in metal bonding, and the possibility of converting the closo cluster into an anionic nido carborane. $^{2 d-f}$ Indeed, only eight different structural motifs which could be classified as potential hemilabile $P, N$ or $P, O$ ligands have been published (Fig. 1). ${ }^{3}$ Among those, only I and II have been employed in homogeneous catalysis so far. ${ }^{3 a, d}$

Previously, we reported the tetradentate ligands VIIIa,b and their coordination chemistry with $\mathrm{Cu}^{\mathrm{I}}$ and $\mathrm{Ag}^{\mathrm{I}}$. Both complexes showed a tetrahedral coordination environment. ${ }^{3 g}$ We reasoned that the combination of VIIIa,b with transition

\footnotetext{
${ }^{a}$ Leipzig University, Faculty of Chemistry and Mineralogy, Institute of Inorganic Chemistry, Johannisallee 29, D-04103 Leipzig, Germany.E-mail: hey@uni-leipzig.de ${ }^{b}$ Chemistry Department, Yildiz Technical University, 34220 Istanbul, Turkey $\dagger$ Electronic supplementary information (ESI) available: Experimental details, NMR investigations, computational details. CCDC 1896567 and 1896568. For ESI and crystallographic data in CIF or other electronic format see DOI: 10.1039/ c9dt00628a
}

metals which prefer square-planar coordination geometries, such as $\mathrm{Rh}^{\mathrm{I}}$, might lead to complexes with interesting structural properties and reactivity.

\section{Results and discussion}

The reaction of VIIIa and VIIIb with $\left[\left\{\operatorname{RhCl}\left(\eta^{4}-\operatorname{cod}\right)\right\}_{2}\right](\operatorname{cod}=$ 1,5-cyclooctadiene) yielded the respective monomeric $\mathrm{Rh}^{\mathrm{I}}$ complexes 1 and 2 . When the reaction is carried out in toluene, the complexes precipitate from the reaction mixture and are obtained in moderate to good yields (Scheme 1). Single crystals of 1 and 2 suitable for X-ray crystallography were obtained from THF/hexane (1) or toluene (2) at r.t. $\mathbf{1}$ crystallises in the Sohncke group $P 2_{1}$ and 2 crystallises in the space group $P \overline{1}$. In both complexes, the rhodium atom exhibits a distorted square-planar coordination geometry with VIIIa,b acting as tridentate $P, P, N$ ligands (Fig. 2).

Especially the $\mathrm{P}-\mathrm{Rh}-\mathrm{N}$ and $\mathrm{P}-\mathrm{Rh}-\mathrm{Cl}$ bond angles deviate significantly from linearity (e.g. 1: P1-Rh1-N1: 156.06(5) ${ }^{\circ}, \mathrm{P} 2-$ Rh1-Cl1: $165.09(2)^{\circ}$, Fig. 2) leading to a geometry index $\tau_{4}$ of 0.27 for 1 and 0.23 for $2 .{ }^{4}$ In fact, these values indicate that 1 and 2 adopt the largest deviation from the ideal square-planar geometry among all $\mathrm{Rh}^{\mathrm{I}}$ complexes featuring two phosphorus donor atoms in a cis arrangement and one nitrogen and one chlorine atom (see the $\mathrm{ESI} \dagger$ for references). In contrast to the bond angles, the $\mathrm{Rh}-\mathrm{P}, \mathrm{Rh}-\mathrm{N}$ and $\mathrm{Rh}-\mathrm{Cl}$ bond lengths in both complexes are within the range of standard values. ${ }^{5}$ The phosphorus atoms trans to the chlorine atoms form significantly shorter Rh-P bonds than the phosphorus atoms cis to chlorine (e.g. 1: Rh1-P1: 2.2028(6), Rh1-P2: 2.1417(6), Fig. 2). This could be due to the trans effect or, as reasoned for a structurally related complex, $[\operatorname{RhCl}(\mathrm{L})](\mathrm{L}=2-(2-\{[3-($ di-tert-butyl- 

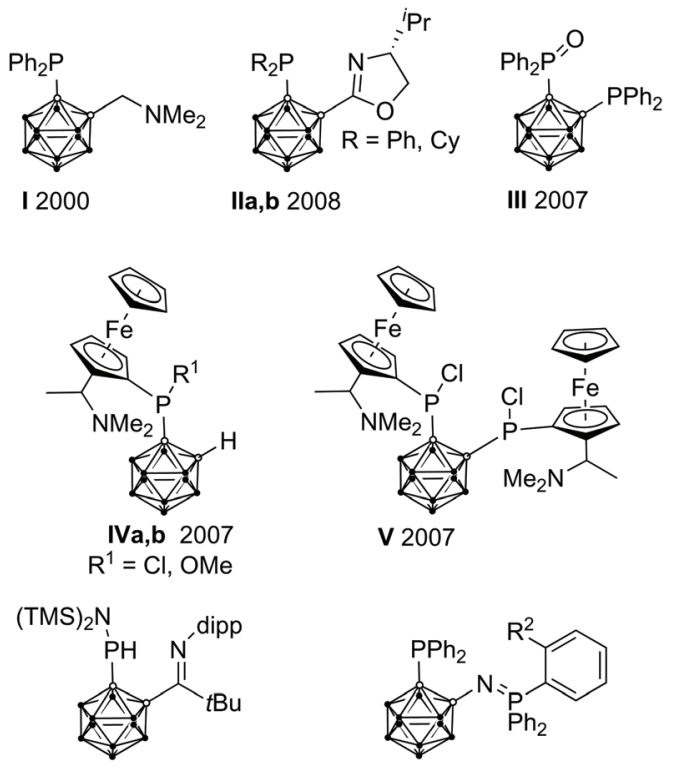

Vla,b 2016 TMS $=$ trimethylsilyl, dipp $=2,5$-diisopropylphenyl

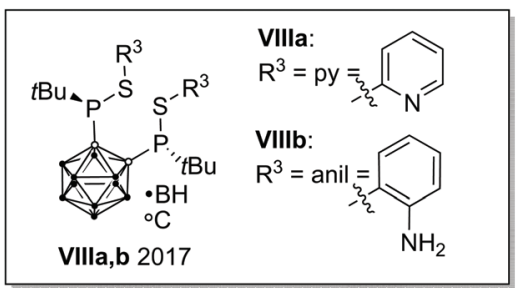

Fig. 1 (Potentially) hemilabile ligand structures containing the orthocarborane backbone.

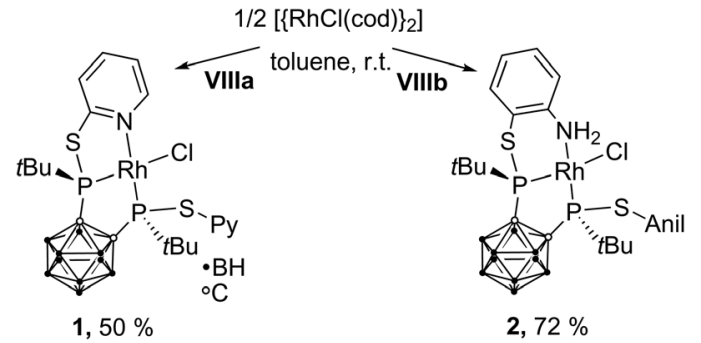

Scheme 1 Synthesis of 1 and 2.1 and 2 were obtained as a racemic mixture. For clarity, in this and all following figures and schemes only one enantiomer is shown.

phosphanyl)propyl]-(phenyl)phosphanyl\}ethyl)pyridine, partly due to the steric repulsion between $\mathrm{Cl} 1$ and the tert-butyl group at $\mathrm{P} 1 .^{5 a}$

We probed the metal-ligand interactions in $\mathbf{1}$ and $\mathbf{2}$ further by $a b$ initio ligand field theory (AILFT as implemented in the ORCA program package) ${ }^{6}$ calculations and energy decomposition analyses at the DFT level (see the ESI $\dagger$ for details). Despite their distorted structures, $\mathbf{1}$ and $\mathbf{2}$ exhibit d orbital splittings similar to an ideal square-planar complex (Fig. 3, left), however the $\mathrm{d}_{x z}$ and $\mathrm{d}_{y z}$ orbitals are not degenerated in our com-

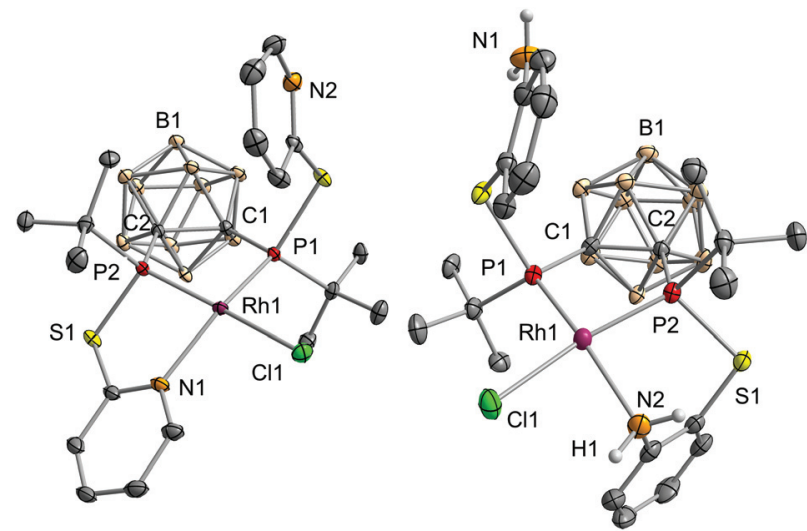

Fig. 2 Molecular structures of $\left(R_{\mathrm{p}}, R_{\mathrm{P}}\right)-1$ (left) and $\left(S_{\mathrm{p}}, S_{\mathrm{P}}\right)-2$ (right) in the solid state with ellipsoids drawn at the $50 \%$ probability level. All hydrogen atoms, except for those at the nitrogen atoms in 2, are omitted for clarity. Selected bond lengths [Å] and angles [ $\left.{ }^{\circ}\right]$ : 1: Rh1-P1: 2.2028(6), Rh1-P2: 2.1417(6), Rh1-N1: 2.160(2), Rh1-Cl1: 2.3930(6), C1-C2: 1.702(3), P1-Rh1-P2: 90.77(2), P1-Rh1-N1: 156.06(5), P1-Rh1-Cl1: 99.45(2), P2-Rh1-N2: 84.43(6), P2-Rh1-Cl1: 165.09(2). 2: Rh1-P1: 2.1958(8), Rh1-P2: 2.1605(9), Rh1-N2: 2.155(3), Rh1-Cl1: 2.396(1), C1C2: 1.701(4), P1-Rh1-P2: 91.20(3), P1-Rh1-N2: 160.48(8), P1-Rh1-Cl1: 101.68(3), P2-Rh1-N2: 88.09(8), P2-Rh1-Cl1: 166.21(3).

plexes. Thereby, the splitting is slightly larger in $\mathbf{1}$ as indicated by the higher $\mathrm{d}_{x^{2}-y^{2}}-\mathrm{d}_{z^{2}}$ separation of $3.58 \mathrm{eV}(2: 3.53 \mathrm{eV})$. These values indicate a slightly stronger metal-ligand interaction in $\mathbf{1}$ as underpinned by the smaller Racah parameter B $\left(649 \mathrm{~cm}^{-1} v s\right.$. $657 \mathrm{~cm}^{-1}$ in 2). Additionally, our energy decomposition analyses revealed that the interaction energy of the ligand with the rhodium centre is higher by $2.7 \mathrm{kcal} \mathrm{mol}^{-1}$ in $\mathbf{1}$.

Due to their different nitrogen donor groups, the overall electronic structure of $\mathbf{1}$ and $\mathbf{2}$ is rather different as shown by our combined UV-vis spectroscopy and TDDFT investigations (see the ESI $\dagger$ ). In diethyl ether, the visible part of the spectra (390 $\mathrm{nm}$ to $700 \mathrm{~nm}$ ) is rather similar for both complexes, exhibiting one metal-to-ligand charge transfer (MLCT) band and several $\mathrm{d}-\mathrm{d}$ transitions. Both spectra predominantly exhibit MLCT bands between 230 and $390 \mathrm{~nm}$, however, their overall shape is significantly different. In particular, the nature of the MLCT bands in 1 and 2 highlights their different electronic structure: in 1, the MLCT bands largely consist of $d-\pi^{*}$ transitions from d orbitals on rhodium to antibonding orbitals of the aromatic systems, while in $2, \mathrm{~d}-\sigma^{*}$ transitions from $\mathrm{d}$ orbitals on rhodium to $\mathrm{P}-\mathrm{C}$ and $\mathrm{P}-\mathrm{S}$ antibonding orbitals dominate. These findings are in accordance with our previous theoretical investigations on the ligands VIIIa,b which showed that the energetically lowest acceptor orbitals of VIIIa are located at the pyridine rings, whereas the acceptor orbitals of VIIIb reside at the phosphorus atoms. ${ }^{3 g}$

Having investigated the electronic structure of $\mathbf{1}$ and 2, we moved on to probe their behaviour in solution. Based on their temperature-dependent NMR spectra, both complexes undergo dynamic processes, which involve the phosphorus atoms and nitrogen donor groups. At low temperatures, the ${ }^{31} \mathrm{P}\left\{{ }^{1} \mathrm{H}\right\}$ NMR spectrum consists of two doublets of doublets $\left(1\left(-40{ }^{\circ} \mathrm{C}\right)\right.$ : 

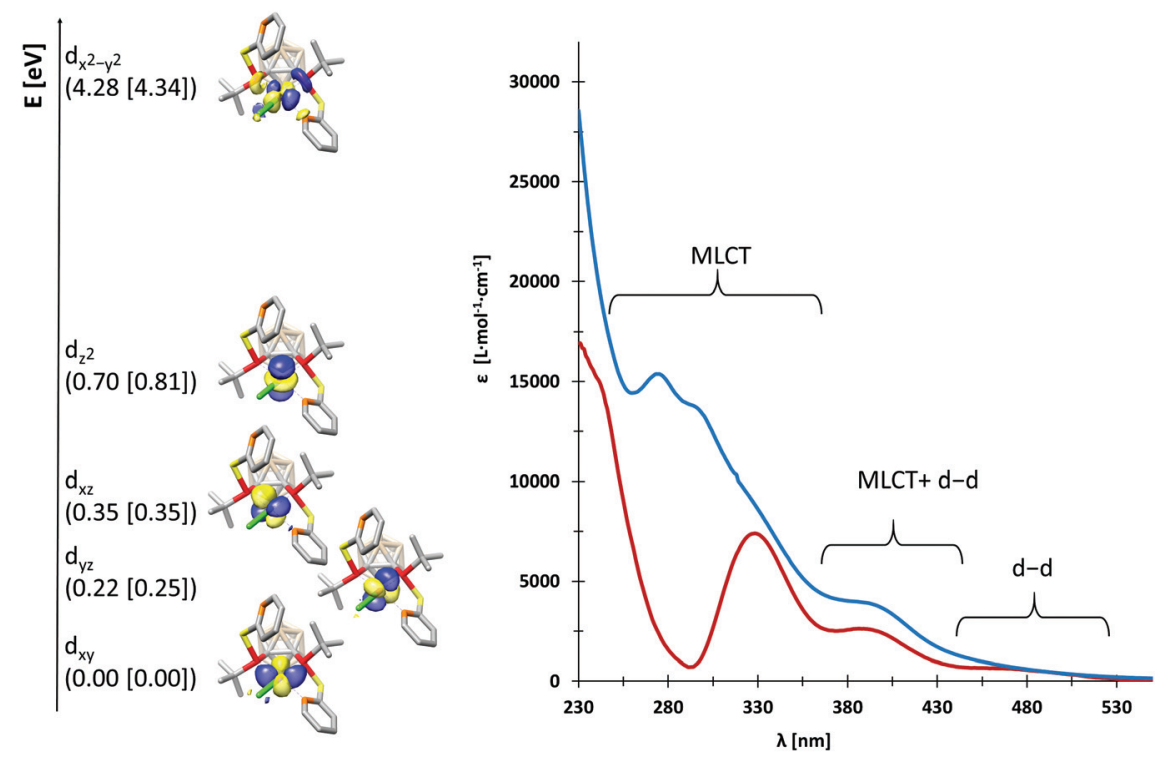

Fig. 3 Left: Orbital scheme for the d orbitals in 1 and 2 (energies for 2 are given in brackets). Exemplarily, the d orbitals for 1 are shown with an isosurface value of 0.05 . Right: UV-vis spectra of 1 (blue) and 2 (red) in diethyl ether.

$150.5\left({ }^{1} J_{\mathrm{PRh}}=219 \mathrm{~Hz}\right)$ and $158.8\left({ }^{1} J_{\mathrm{PRh}}=186 \mathrm{~Hz}\right) \mathrm{ppm},{ }^{2} J_{\mathrm{PP}}=38$ $\mathrm{Hz} ; 2\left(-5^{\circ} \mathrm{C}\right): 162.4\left({ }^{1} J_{\mathrm{PRh}}=230 \mathrm{~Hz}\right)$ and $195.7\left({ }^{1} J_{\mathrm{PRh}}=216 \mathrm{~Hz}\right)$ ppm, $\left.{ }^{2} J_{\mathrm{PP}}=40 \mathrm{~Hz}\right)$. Due to the higher P-Rh coupling constants, the multiplets at 158.8 and $195.7 \mathrm{ppm}$ are tentatively assigned to P2, which forms a shorter P-Rh bond than P1 in both complexes (Fig. 2). For 1, a broad singlet is observed at $154.4 \mathrm{ppm}\left(\nu_{\mathrm{FWHM}}=530 \mathrm{~Hz}\right)$ at $60{ }^{\circ} \mathrm{C}$ (see the ESI $\left.\dagger\right)$; in contrast, the signals in the ${ }^{31} \mathrm{P}\left\{{ }^{1} \mathrm{H}\right\}$ NMR spectrum of 2 just broaden at higher temperature. Together with an analysis of the temperature-dependent ${ }^{1} \mathrm{H}$ NMR spectra of $\mathbf{1}$ and 2 , this observation proves a higher activation barrier for the dynamic processes in $\mathbf{2}$ compared to $\mathbf{1}$.

In order to get further insight, we calculated the mechanism of the dynamic process for both complexes at the DFT level (see the ESI $\dagger$ for details), which is depicted for $\mathbf{1}$ in Scheme 2. A similar mechanism was proposed for $\mathrm{Pd}^{\mathrm{II}}$ and $\mathrm{Pt}^{\mathrm{II}}$ complexes of a structurally related ligand, 1,3-bis\{methyl[2(pyridin-2-yl)ethyl]phosphanyl\}propane. ${ }^{5 a}$ The mechanism involves the formation of a distorted square-pyramidal intermediate 1-qpym, in which VIIIa acts as a tetradentate ligand. 1-qpym isomerises to 1-qpym' via a rocking vibration involving the chlorine atom. Finally, one nitrogen donor group in 1-qpym' dissociates to form 1'. This process equilibrates both the phosphorus atoms and pyridyl groups in 1. A very similar mechanism was determined for complex 2 (see the ESI $\dagger$ for details). The first step (a, Scheme 2) is rate determining for both complexes. In agreement with our NMR spectroscopy experiments, the activation energy for the formation of the square-pyramidal complexes 1-qpym or 2-qpym, respectively, is considerably higher in the case of $2\left(19.4 \mathrm{kcal} \mathrm{mol}^{-1}\right.$ vs. $11.5 \mathrm{kcal} \mathrm{mol}^{-1}$ ). Our calculations show that the higher energy barrier in 2 can be traced back to steric effects and is caused by the structural rearrangements necessary to adopt

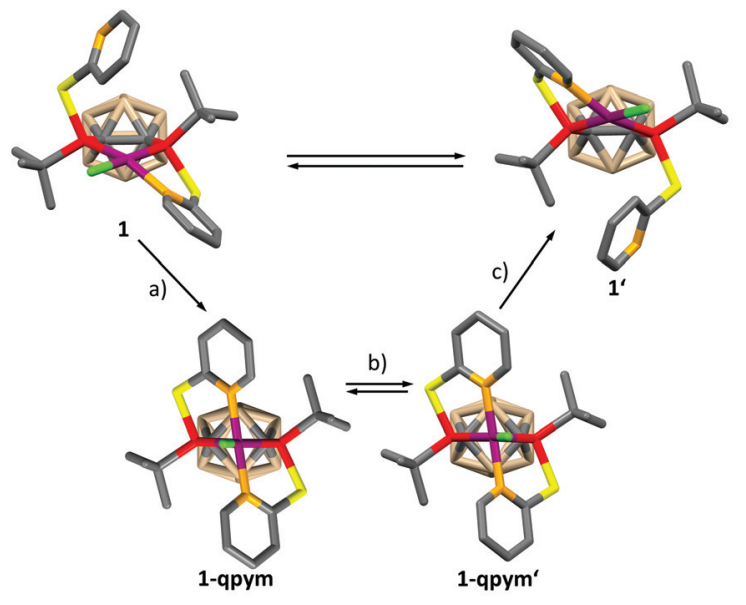

$$
\text { a): } \begin{aligned}
\Delta \mathrm{E} & =11.2, \Delta \mathrm{E}^{\dagger}=11.5 & \text { b): } \Delta \mathrm{E}=0.0, \Delta \mathrm{E}^{\dagger}=0.3 & \mathrm{c}): \Delta \mathrm{E}=-11.2, \Delta \mathrm{E}^{\dagger}=0.3 \\
(\Delta \mathrm{E} & \left.=18.5, \Delta \mathrm{E}^{\dagger}=19.4\right) & \left(\Delta \mathrm{E}=0.0, \Delta \mathrm{E}^{\dagger}=0.9\right) & \left(\Delta \mathrm{E}=-18.5, \Delta \mathrm{E}^{\dagger}=0.9\right)
\end{aligned}
$$

Scheme 2 Calculated mechanism of the dynamic processes in 1. Energy differences are given in $\mathrm{kcal} \mathrm{mol}^{-1}$. Energy differences are given relative to 1 (or 2 ) in step (a), relative to 1-qpym (or 2-qpym) in step (b) and relative to 1-qpym' in step (c). Values in parentheses correspond to the values calculated for the respective structures with the ligand VIIIb. Hydrogen atoms have been omitted for clarity.

the tetra-coordinating geometry of the ligand in 2-qpym (see the ESI $\dagger$ ).

The tetra-coordination of the ligands in $\mathbf{1}$ and $\mathbf{2}$ also has a great influence on their electrochemistry. Both complexes undergo an irreversible reduction in the typical range of carborane derivatives $\left(\mathbf{1}^{-} / \mathbf{1}: E_{\text {peak(cathodic) }}=-1.88 \mathrm{~V}, 2^{-} / 2\right.$ : $E_{\text {peak(cathodic) }}=-1.95 \mathrm{~V}$, vs. $\left.\mathrm{FcH} /[\mathrm{FcH}]^{+}\right),{ }^{7}$ and our calculations confirm that the reduction of $\mathbf{1}$ and $\mathbf{2}$ occurs at the carborane 
backbone based on the spin densities of the monoanions $\mathbf{1}^{-}$ and $2^{-}$(Fig. 4). The reduction is accompanied by a change to a square-pyramidal structure in $\mathbf{1}^{-}$, whereas the distorted square-planar structure is retained in $2^{-}$(see the ESI $\dagger$ for details). For both 1 and 2 the calculated reduction potentials agree well with the measured cathodic peak potentials $\left(\mathbf{1}^{-} / \mathbf{1}\right.$ : $-2.14 \mathrm{~V}, 2^{-} / 2:-2.07 \mathrm{~V}, v s . \mathrm{FcH} /[\mathrm{FcH}]^{+}$, see the $\mathrm{ESI} \dagger$ for details).

At higher potentials, 1 is oxidised in two steps. While the first event appears to be quasi-reversible, the second is irreversible $\left(\mathbf{1} / \mathbf{1}^{+}: E_{1 / 2}=-588 \mathrm{mV}, \mathbf{1}^{+} / \mathbf{1}^{2+}: E_{\text {peak(anodic) }}=-296 \mathrm{mV}\right.$, vs. $\left.\mathrm{FcH} /[\mathrm{FcH}]^{+}\right)$. Complex 2 behaves similarly; however, both oxidation events are irreversible and appear at significantly higher potentials $\left(2 / 2^{+}: E_{\text {peak(anodic) }}=-27 \mathrm{mV}, 2^{+} / 2^{2+}\right.$ : $E_{\text {peak }(\text { anodic })}=149 \mathrm{mV}$, vs. $\mathrm{FcH} /[\mathrm{FcH}]^{+}$). As for the reductions, our calculated oxidation potentials for the first oxidation events of $\mathbf{1}$ and $\mathbf{2}$ are in good agreement ${ }^{8}$ with the experimental values $\left(\mathbf{1} / \mathbf{1}^{+}:-800 \mathrm{mV}, 2 / 2^{+}:-150 \mathrm{mV}\right.$, vs. $\mathrm{FcH} /[\mathrm{FcH}]^{+}$, see the ESI $\dagger$ for details) and reveal that these oxidations take place at the rhodium centre (Fig. 4). Both oxidation events in $\mathbf{1}$ and $\mathbf{2}$ are accompanied by a structural change to a distorted square-pyramidal structure, again underpinning the influence of the tetra-coordination of the ligands on the properties of $\mathbf{1}$ and 2.

Finally, we explored the use of $\mathbf{1}$ and $\mathbf{2}$ as homogeneous catalysts. As a model reaction, we investigated the dehydrocoupling of dimethylamine-borane (3) to give the diazadiboretidine derivative $\mathbf{4}$ and molecular hydrogen (Scheme 3) in toluene- $\mathrm{d}_{8}$. This reaction was initially conducted with $\left[\{\mathrm{RhCl}(\mathrm{cod})\}_{2}\right]$ as catalyst. ${ }^{9}$ Since then, a variety of transition metal complexes, including zirconium, iridium and cobalt, was shown to efficiently catalyse this reaction. ${ }^{10}$ Our results indicate that both 1 and 2 convert 3 completely and at comparable rate like $\left[\{\operatorname{RhCl}(\mathrm{cod})\}_{2}\right]$ (Scheme 3 , see the ESI $\dagger$ for
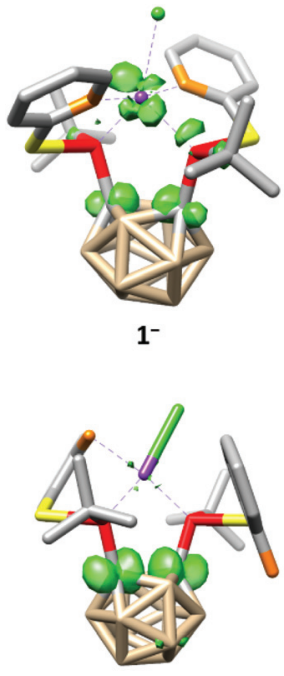

$\mathbf{2}^{-}$

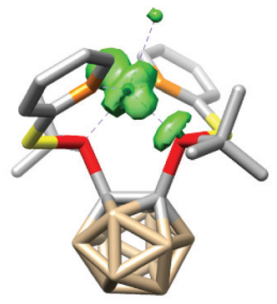

$\mathbf{1}^{+}$

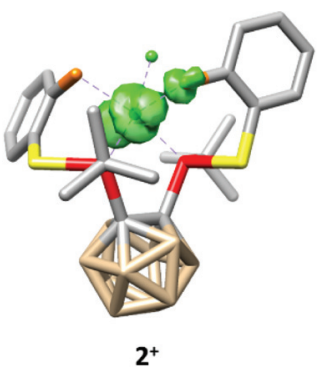

$\mathbf{2}^{+}$
Fig. 4 Calculated spin densities (green, surface isovalue $=0.05$ ) and structures of $1^{-}, 1^{+}, 2^{-}$and $2^{+}$. Hydrogen atoms have been omitted for clarity.

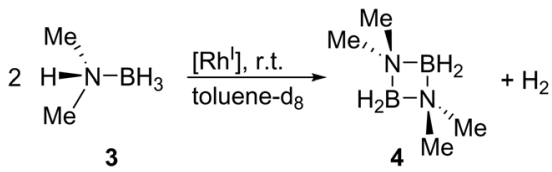

a) $\left[\mathrm{Rh}^{\prime}\right]=\left[\{\mathrm{RhCl}(\mathrm{cod})\}_{2}\right], 1 \mathrm{~mol} \%, \mathrm{t}=24 \mathrm{~h}(88 \%$ yield $)$

b) $\left[\mathrm{Rh}^{\prime}\right]=1,2 \mathrm{~mol} \%, \mathrm{t}=72 \mathrm{~h}$ (35\% yield)

c) $\left[\mathrm{Rh}^{\prime}\right]=2,2 \mathrm{~mol} \%, \mathrm{t}=48 \mathrm{~h}(77 \%$ yield $)$

Scheme 3 Performance of $\left[\{\mathrm{RhCl}(\operatorname{cod})\}_{2}\right], 1$ and 2 in the dehydrocoupling of dimethylamine-borane (3).

details). However, they are much less selective, especially in the case of $\mathbf{1}$, producing a significant amount of the aminoborane $\mathrm{HB}\left(\mathrm{NMe}_{2}\right)_{2}$ and an unidentified side product. However, this side product decomposes slowly under the reaction conditions, whereas the desired cyclic product $\mathbf{4}$ is stable, leading to 4 as the only product detectable by ${ }^{11} \mathrm{~B}$ NMR spectroscopy (1: after $72 \mathrm{~h} ; 2$ : after $48 \mathrm{~h}$ ). Due to the formation of this side product, the yield of $\mathbf{4}$ is reduced compared to $\left[\{\mathrm{RhCl}(\operatorname{cod})\}_{2}\right]$. The different performance of the catalysts 1 and 2 might be explained by the different nitrogen-donor groups present in both complexes. In 2 , the aniline groups present a much stronger Lewis base than the pyridine groups in $\mathbf{1}$. Therefore, the aniline groups in $\mathbf{2}$ might interact more strongly with the Lewis-acidic substrate (dimethylamine-borane) leading to a more selective reaction. However, further kinetic and computational studies would be required for definite conclusions.

\section{Conclusions}

In summary, we have prepared and thoroughly characterised two distorted square-planar $\mathrm{Rh}^{\mathrm{I}}$ complexes with tetradentate, hemilabile carborane-substituted $P, N$ ligands. The coordination mode of these ligands strongly influences the dynamic behaviour in solution as well as the redox properties of $\mathbf{1}$ and 2. Both complexes catalyse the dehydrocoupling reactions of amine-boranes, but are less active and selective than $\left[\{\operatorname{RhCl}(\operatorname{cod})\}_{2}\right]$. However, due to their significantly distorted structure and hemilabile ligands, they could be more promising in other reactions. Respective investigations are currently underway in our group.

\section{Experimental}

\section{Materials and methods}

All reactions and manipulations were carried out under a nitrogen atmosphere by using standard Schlenk techniques unless stated otherwise. Solvents were either obtained from an MBraun Solvent Purification System, or dried and stored according to common procedures. ${ }^{11}$ Dimethylamine-borane is commercially available and was used as obtained. [ $\{\mathrm{RhCl}-$ (cod) $\left.\}_{2}\right]$ and ligands VIIIa and VIIIb were synthesised according to literature procedures. ${ }^{3 g, 12}$ NMR spectra were recorded with a Bruker AVANCE DRX $400 \mathrm{MHz}$ NMR spectrometer at room 
temperature. All isolated compounds were measured in deuterated tetrahydrofuran $\left(\mathrm{THF}-\mathrm{d}_{8}\right)$. Tetramethylsilane was used as internal standard for ${ }^{1} \mathrm{H}$ NMR spectra. $85 \% \mathrm{H}_{3} \mathrm{PO}_{4}$ was used as external standard for ${ }^{31} \mathrm{P}\left\{{ }^{1} \mathrm{H}\right\}$ NMR spectra, and $\mathrm{BF}_{3} \cdot \mathrm{OEt}_{2}$ was used as external standard for ${ }^{11} \mathrm{~B}\left\{{ }^{1} \mathrm{H}\right\}$ NMR spectra. NMR spectra were recorded at the following frequencies: ${ }^{1} \mathrm{H}$ : 400.13 MHz, ${ }^{11} \mathrm{~B}: 128.38 \mathrm{MHz},{ }^{31} \mathrm{P}: 161.99 \mathrm{MHz}$. IR spectra were recorded as ATR spectra in the range of $4000-640 \mathrm{~cm}^{-1}$ with a Bruker TENSOR 27 IR spectrometer.

\section{Crystallography}

X-ray diffraction studies on $\mathbf{1}$ were performed with an Agilent Technologies SuperNova diffractometer using $\mathrm{Cu}-\mathrm{K} \alpha$ radiation and $\omega$-scan rotation. X-ray diffraction studies on 2 were performed with an Oxford Diffraction CCD Xcalibur-S diffractometer using Mo-K $\alpha$ radiation and $\omega$-scan rotation. Data were collected using $\omega$ steps accumulating area detector frames (data reduction was carried out with CrysAlis Pro). ${ }^{13}$ All data were corrected for Lorentz polarisation and long-term intensity fluctuations. Absorption effects were corrected based on analytical corrections for $\mathbf{1}$ and on the basis of multiple equivalent reflections for 2 . Structures were solved by direct methods and refined by full-matrix least-squares techniques against $F^{2}$ using the SHELX program package. ${ }^{14}$ Hydrogen atoms were assigned riding isotropic displacement parameters and constrained to idealised geometries. Structure figures were generated with DIAMOND (Table 1$).{ }^{15}$ The crystal structures of 1 and 2 have been deposited in the CCDC (1: 1896568, 2: 1896567$) \dagger$

\section{Synthetic procedures}

$\left[\{\mathrm{RhCl}(\mathrm{cod})\}_{2}\right]$ (46 mg, $0.09 \mathrm{mmol}, 0.500 \mathrm{eq}$.) and the respective ligand (1: ligand VIIIa: $101 \mathrm{mg}, 0.19 \mathrm{mmol}, 1.06$ eq.; 2: ligand VIIIb: $100 \mathrm{mg}, 0.18 \mathrm{mmol}, 1.00 \mathrm{eq}$.) were dissolved in toluene

Table 1 Crystal data and refinement parameters for 1 and 2

\begin{tabular}{|c|c|c|}
\hline Compound & 1 & 2 \\
\hline Empirical formula & $\mathrm{C}_{20} \mathrm{H}_{36} \mathrm{~B}_{10} \mathrm{ClN}_{2} \mathrm{P}_{2} \mathrm{RhS}_{2}$ & $\mathrm{C}_{22} \mathrm{H}_{40} \mathrm{~B}_{10} \mathrm{ClN}_{2} \mathrm{P}_{2} \mathrm{RhS}_{2}$ \\
\hline Formula weight & 677.03 & 705.08 \\
\hline$T[\mathrm{~K}]$ & 123 & 130 \\
\hline Crystal system & Monoclinic & Triclinic \\
\hline Space group & $P 2_{1}$ & $P \overline{1}$ \\
\hline$a[\AA]$ & $9.5859(2)$ & $9.4717(2)$ \\
\hline$b[\AA]$ & $13.2274(2)$ & $10.4441(3)$ \\
\hline$c[\AA]$ & $11.9819(2)$ & $16.3936(4)$ \\
\hline$\alpha$ & 90 & $88.649(2)$ \\
\hline$\beta$ & $103.849(2)$ & $75.070(2)$ \\
\hline$\gamma$ & 90 & $89.069(2)$ \\
\hline$V\left[\AA^{3}\right]$ & $1475.10(5)$ & $1566.44(7)$ \\
\hline$Z$ & 2 & 2 \\
\hline$\rho_{\text {calcd }}\left[\mathrm{g} \mathrm{cm}^{-3}\right]$ & 1.524 & 1.495 \\
\hline$\theta_{\max }$ & 30.679 & 28.281 \\
\hline$F(000)$ & 688 & 720 \\
\hline Reflns collected & 9062 & 24286 \\
\hline Independent reflns & 4139 & 7337 \\
\hline$R_{1} / \mathrm{w} R_{2}[I>2 \sigma(I)]$ & $0.0150 / 0.0387$ & $0.0415 / 0.0763$ \\
\hline$R_{1} / \mathrm{w} R_{2}$ (all data) & $0.0150 / 0.0387$ & $0.0615 / 0.0823$ \\
\hline $\begin{array}{l}\text { Largest diff. peak/ } \\
\left.\text { hole/(e } \AA^{-3}\right)\end{array}$ & $0.289 /-0.350$ & $0.775 /-0.496$ \\
\hline
\end{tabular}

and stirred for $2 \mathrm{~d}$. The resulting suspensions were filtered, and the residues were washed with toluene $(2 \times 2 \mathrm{~mL})$ to afford 1 (64 mg, 50\% yield) or 2 (90 mg, 72\% yield) as orange solids. Single crystals of 1 suitable for X-ray diffraction studies were obtained by layering a saturated THF solution with $n$-hexane. In the case of 2 , single crystals were obtained directly from the reaction mixture when stirring was discontinued after the reactants had dissolved. 1: IR: $\tilde{\nu}=3063(\mathrm{~m}, \nu \mathrm{C}-\mathrm{H}), 3043(\mathrm{~m}, \nu \mathrm{C}-\mathrm{H})$, $3018(\mathrm{~m}, \nu \mathrm{C}-\mathrm{H}), 3002(\mathrm{~m}, \nu \mathrm{C}-\mathrm{H}), 2981$ (m, $\nu \mathrm{C}-\mathrm{H}), 2958(\mathrm{~m}$, $\nu \mathrm{C}-\mathrm{H}), 2957$ (m, $\nu \mathrm{C}-\mathrm{H}), 2902(\mathrm{~m}, \nu \mathrm{C}-\mathrm{H}), 2863(\mathrm{~m}, \nu \mathrm{C}-\mathrm{H}), 2648$ (s, $\nu \mathrm{B}-\mathrm{H}), 2620(\mathrm{~s}, \nu \mathrm{B}-\mathrm{H}), 2611(\mathrm{~s}, \nu \mathrm{B}-\mathrm{H}), 2594(\mathrm{~s}, \nu \mathrm{B}-\mathrm{H}), 2569$ (vs, $\nu \mathrm{B}-\mathrm{H}), 2008(\mathrm{w}), 1981(\mathrm{w}), 1960(\mathrm{w}), 1892(\mathrm{w}), 1872(\mathrm{w})$, $1847(\mathrm{w}), 1587(\mathrm{~m}), 1582(\mathrm{~m}), 1576(\mathrm{~m}), 1449(\mathrm{~s}), 1415(\mathrm{~m})$, $1394(\mathrm{~m}), 1364(\mathrm{~m}), 1302(\mathrm{w}), 1262(\mathrm{w}), 1167(\mathrm{~m}), 1164(\mathrm{~m})$, $1111(\mathrm{~m}), 1070(\mathrm{~m}), 1009(\mathrm{~m}), 987(\mathrm{~m}), 904(\mathrm{w}), 888(\mathrm{w}), 863$ (w), 826 (w), 801 (s), 776 (s), $733(\mathrm{w}), 720(\mathrm{w}), 649$ (w) cm $\mathrm{cm}^{-1}$. UVvis $\left(\mathrm{Et}_{2} \mathrm{O}\right): \lambda_{\max }=398\left(\varepsilon=3713 \mathrm{~cm} \mathrm{~L} \mathrm{~mol}^{-1}\right), 298$ (shoulder, $\varepsilon=$ $13497 \mathrm{~cm} \mathrm{~L} \mathrm{~mol}^{-1}$ ), $273\left(\varepsilon=15375 \mathrm{~cm} \mathrm{~L} \mathrm{~mol}^{-1}\right) \mathrm{nm}$. Anal. calcd for $\mathrm{C}_{20} \mathrm{H}_{36} \mathrm{~B}_{10} \mathrm{ClN}_{2} \mathrm{P}_{2} \mathrm{RhS}_{2}$ : C 35.48, H 5.36, N 4.14. Found: C 35.56, H 5.10, N 3.91. ${ }^{1} \mathrm{H}$ NMR: $\delta=1.33$ (bs, $18 \mathrm{H}$, $\left.\mathrm{CH}_{3}\right), 1.28-3.60(\mathrm{~m}, 10 \mathrm{H}, \mathrm{BH}), 7.25\left(\mathrm{ddd},{ }^{3} J_{\mathrm{HH}}=7.3 \mathrm{~Hz},{ }^{3} J_{\mathrm{HH}}=\right.$ $5.5 \mathrm{~Hz},{ }^{4} J_{\mathrm{HH}}=1.2 \mathrm{~Hz}, 2 \mathrm{H}$, arom. $\left.\mathrm{CH}\right), 7.75\left(\mathrm{td},{ }^{3} J_{\mathrm{HH}}=7.8 \mathrm{~Hz}\right.$, ${ }^{4} J_{\mathrm{HP}}=1.9 \mathrm{~Hz}, 2 \mathrm{H}$, arom. $\mathrm{CH}$ ), 8.36 (bs, 2H, arom. $\mathrm{CH}$ ), 8.96 (bs, $2 \mathrm{H}$, arom. $\mathrm{CH}$ ) ppm. ${ }^{1} \mathrm{H}\left\{{ }^{11} \mathrm{~B}\right\}$ NMR $\delta=1.31$ (bs, $18 \mathrm{H}, \mathrm{CH}_{3}$ ), 2.41- 2.45 (m, 3H, BH), 2.54 (s, 2H, BH), 2.63 (s, 3H, BH), 3.45 (s 2H, BH), 7.25-7.28 (m, 2H, arom. $\mathrm{CH}), 7.76\left(\mathrm{td},{ }^{3} J_{\mathrm{HH}}=7.8\right.$ $\mathrm{Hz},{ }^{4} J_{\mathrm{HP}}=1.9 \mathrm{~Hz}, 2 \mathrm{H}$, arom. $\mathrm{CH}$ ), 8.39 (bs, 2H, arom. $\mathrm{CH}$ ), 8.98 (bs, 2H, arom. $\mathrm{CH}$ ) ppm. ${ }^{11} \mathrm{~B}\left\{{ }^{1} \mathrm{H}\right\}$ NMR: $\delta=-9.3$ (bs, 6B), -4.6 (bs, 2B), -1.3 (bs, 2B) ppm. ${ }^{11} \mathrm{~B}$ NMR: $\delta=-10.0$ to $-8.7(\mathrm{~m}$, 6B), $-4.6\left(\mathrm{~d},{ }^{1} J_{\mathrm{BH}}=144 \mathrm{~Hz}, 2 \mathrm{~B}\right),-1.3\left(\mathrm{~d},{ }^{1} J_{\mathrm{BH}}=153 \mathrm{~Hz}, 2 \mathrm{~B}\right)$ ppm. ${ }^{31} \mathrm{P}\left\{{ }^{1} \mathrm{H}\right\}$ NMR (r.t.): $\delta=151.8$ (bs), 159.9 (bs) ppm. ${ }^{31} \mathrm{P}\left\{{ }^{1} \mathrm{H}\right\}$ $\operatorname{NMR}\left(-40{ }^{\circ} \mathrm{C}\right): \delta=150.5\left(\mathrm{dd},{ }^{1} J_{\mathrm{PRh}}=219 \mathrm{~Hz},{ }^{2} J_{\mathrm{PP}}=38 \mathrm{~Hz}\right)$, $158.8\left(\mathrm{dd},{ }^{1} J_{\mathrm{PRh}}=186 \mathrm{~Hz},{ }^{2} J_{\mathrm{PP}}=38 \mathrm{~Hz}\right)$ ppm. 2: IR: $\tilde{\nu}=3484(\mathrm{~s}$, $\nu \mathrm{N}-\mathrm{H}), 3385(\mathrm{~m}, \nu \mathrm{N}-\mathrm{H}), 3313(\mathrm{~m}, \nu \mathrm{N}-\mathrm{H}), 3245(\mathrm{~m}, \nu \mathrm{N}-\mathrm{H}), 3015$ (m, $\nu \mathrm{C}-\mathrm{H}), 3022(\mathrm{~m}, \nu \mathrm{C}-\mathrm{H}), 3001$ (m, $\nu \mathrm{C}-\mathrm{H}), 2947$ (m, $\nu \mathrm{C}-\mathrm{H})$, 2927 (m, $\nu \mathrm{C}-\mathrm{H}), 2866$ (m, $\nu \mathrm{C}-\mathrm{H}), 2631$ (s, $\nu \mathrm{B}-\mathrm{H}), 2557$ (vs, $\nu \mathrm{B}-$ H), 1609 (s), 1588 (m), 1545 (s), 1477 (s), 1446 (m), 1395 (m), 1257 (m), 1171 (m), 1158 (m), 1141 (w), 1068 (s), 1015 (s), 970 (w), 931 (m), 904 (w), 858 (w), 802 (m), 745 (vs), 676 (w) cm $\mathrm{cm}^{-1}$. UV-vis $\left(\mathrm{Et}_{2} \mathrm{O}\right): \lambda_{\max }=471\left(\varepsilon=622 \mathrm{~cm} \mathrm{~L} \mathrm{~mol}^{-1}\right), 389(\varepsilon=$ $2611 \mathrm{~cm} \mathrm{~L} \mathrm{~mol}^{-1}$ ), 328 ( $\varepsilon=7393 \mathrm{~cm} \mathrm{~L} \mathrm{~mol}^{-1}$ ), 243 (shoulder, $\varepsilon=14637 \mathrm{~cm} \mathrm{~L} \mathrm{~mol}^{-1}$ ) nm. Anal. calcd for $\mathrm{C}_{22} \mathrm{H}_{40} \mathrm{~B}_{10} \mathrm{ClN}_{2} \mathrm{P}_{2} \mathrm{RhS}_{2}$ : C 37.48, H 5.72, N 3.97. Found: C 37.86, H 5.63, N 3.91. ${ }^{1} \mathrm{H}$ NMR: $\delta=1.20\left(\mathrm{bd},{ }^{3} J_{\mathrm{HP}}=15.4 \mathrm{~Hz}, 18 \mathrm{H}, \mathrm{CH}_{3}\right), 1.28-3.44(\mathrm{~m}$, $10 \mathrm{H}, \mathrm{BH}), 5.01$ (bs, 2H, NH), 5.46 (bs, 1H, NH), 5.75 (bs, 1H, $\mathrm{NH}$ ), 6.59-6.64 (m, 2H, arom. $\mathrm{CH}), 7.01$ (bs, 2H, arom. $\mathrm{CH})$, $7.15\left(\mathrm{bd},{ }^{3} J_{\mathrm{HH}}=8.1 \mathrm{~Hz}, 1 \mathrm{H}\right.$, arom. $\left.\mathrm{CH}\right), 7.25-7.27(\mathrm{~m}, 1 \mathrm{H}$, arom. $\mathrm{CH}$ ), 7.48 (bd, ${ }^{3} J_{\mathrm{HH}}=7.7 \mathrm{~Hz}, 1 \mathrm{H}$, arom. $\mathrm{CH}$ ), 8.54 (bd, ${ }^{3} J_{\mathrm{HH}}=7.8 \mathrm{~Hz}, 1 \mathrm{H}$, arom. CH) ppm. ${ }^{1} \mathrm{H}\left\{{ }^{11} \mathrm{~B}\right\}$ NMR: $\delta=1.22(\mathrm{bd}$, $\left.{ }^{3} J_{\mathrm{HP}}=15.4 \mathrm{~Hz}, 18 \mathrm{H}, \mathrm{CH}_{3}\right), 2.16$ (bs, $\left.1 \mathrm{H}, \mathrm{BH}\right), 2.29-2.35(\mathrm{~m}, 3 \mathrm{H}$, $\mathrm{BH}$ ), 2.46 (bs, 2H, BH), 2.68 (bs, 3H, BH), 2.88 (bs, 1H, BH), 5.01 (bs, 2H, NH), 5.47 (bs, 1H, NH), 5.76 (bs, 1H, NH), 6.62 (bs, 2H, arom. $\mathrm{CH}$ ), 7.02 (bs, 2H, arom. $\mathrm{CH}$ ), 7.16 (bs, $1 \mathrm{H}$, arom. $\mathrm{CH}$ ), 7.28 (bs, $1 \mathrm{H}$, arom. $\mathrm{CH}$ ), 7.49 (bs, $1 \mathrm{H}$, arom. $\mathrm{CH}$ ), 8.58 (bs, $1 \mathrm{H}$, arom. $\mathrm{CH}$ ) ppm. ${ }^{11} \mathrm{~B}\left\{{ }^{1} \mathrm{H}\right\}$ NMR: $\delta=-11.3$ (bs, 4B), -8.3 (bs, 2B), -4.8 (bs, 1B), -2.3 (bs, 3B) ppm. ${ }^{11} \mathrm{~B}$ NMR: 
$\delta=-14.0$ to $-8.2(\mathrm{~m}, 6 \mathrm{~B}),-5.4$ to $-1.8(\mathrm{~m}, 4 \mathrm{~B}) \mathrm{ppm} .{ }^{31} \mathrm{P}\left\{{ }^{1} \mathrm{H}\right\}$ NMR (r.t.): $\delta=161.9$ (dd, ${ }^{1} J_{\mathrm{PRh}}=230 \mathrm{~Hz},{ }^{2} J_{\mathrm{PP}}=39 \mathrm{~Hz}$ ), 195.5 $\left(\mathrm{dd},{ }^{1} J_{\mathrm{PRh}}=218 \mathrm{~Hz},{ }^{2} J_{\mathrm{PP}}=44 \mathrm{~Hz}\right) \mathrm{ppm} .{ }^{31} \mathrm{P}\left\{{ }^{1} \mathrm{H}\right\} \mathrm{NMR}\left(-5^{\circ} \mathrm{C}\right)$ : $\delta=162.4\left(\mathrm{dd},{ }^{1} J_{\mathrm{PRh}}=230 \mathrm{~Hz},{ }^{2} J_{\mathrm{PP}}=40 \mathrm{~Hz}\right), 195.7\left(\mathrm{dd},{ }^{1} J_{\mathrm{PRh}}=\right.$ $\left.216 \mathrm{~Hz},{ }^{2} J_{\mathrm{PP}}=41 \mathrm{~Hz}\right) \mathrm{ppm}$.

\section{Conflicts of interest}

There are no conflicts to declare.

\section{Acknowledgements}

Financial support by the Studienstiftung des deutschen Volkes (doctoral fellowships to P. C. and A. S.), TUBITAK 2214-A (research fellowship to G. K.) and the Graduate School BuildMoNa is gratefully acknowledged. We thank Prof. R. Wolf (Regensburg University) for X-ray measurement time.

\section{Notes and references}

1 (a) P. Espinet and K. Soulantica, Coord. Chem. Rev., 1999, 193-195, 499-556; (b) P. Braunstein and F. Naud, Angew. Chem., Int. Ed., 2001, 40, 680-699, (Angew. Chem., 2001, 113, 702-722); (c) V. V. Grushin, Chem. Rev., 2004, 104, 1629-1662.

2 (a) S. P. Fisher, A. W. Tomich, S. O. Lovera, J. F. Kleinsasser, J. Guo, M. J. Asay, H. M. Nelson and V. Lavallo, Chem. Rev., 2019, DOI: 10.1021/acs.chemrev.8b00551; (b) B. J. Eleazer, M. D. Smith, A. A. Popov and D. V. Peryshkov, Chem. Sci., 2018, 9, 2601-2608; (c) A. M. Spokoyny, C. W. Machan, D. J. Clingerman, M. S. Rosen, M. J. Wiester, R. D. Kennedy, C. L. Stern, A. A. Sarjeant and C. A. Mirkin, Nat. Chem., 2011, 3, 590596; (d) V. I. Bregadze, Chem. Rev., 1992, 92, 209-223; (e) M. Scholz and E. Hey-Hawkins, Chem. Rev., 2011, 111, 7035-7062; $(f)$ A. R. Popescu, F. Teixidor and C. Viñas, Coord. Chem. Rev., 2014, 269, 54-84.

3 (a) H.-S. Lee, J.-Y. Bae, J. Ko, Y. S. Kang, H. S. Kim, S.-J. Kim, J.-H. Chung and S. O. Kang, J. Organomet. Chem., 2000, 614-615, 83-91; (b) J. Dou, D. Zhang, D. Li and D. Wang, Eur. J. Inorg. Chem., 2007, 2007, 53-59; (c) S. Tschirschwitz, P. Lönnecke and E. Hey-Hawkins, Organometallics, 2007, 26, 4715-4724; (d) J.-D. Lee, T. T. Co, T.-J. Kim and S. O. Kang, Synlett, 2009, 771-774; (e) A. Herrera, A. Briceño, T. Gonzalez, A. Linden, F. W. Heinemann, G. Agrifoglio, J. Pastrán and R. Dorta, Tetrahedron: Asymmetry, 2016, 27, 759-767; $(f)$ P. Crujeiras,
J. L. Rodríguez-Rey and A. Sousa-Pedrares, Eur. J. Inorg. Chem., 2017, 2017, 4653-4667; (g) P. Coburger, J. Schulz, J. Klose, B. Schwarze, M. B. Sárosi and E. Hey-Hawkins, Inorg. Chem., 2017, 56, 292-304.

$4 \tau_{4}=0$ represents an ideal square-planar complex, and $\tau_{4}=1$ represents the case of an ideal tetrahedral complex: L. Yang, D. R. Powell and R. P. Houser, Dalton Trans., 2007, 955-964.

5 (a) A. Heßler, J. Fischer, S. Kucken and O. Stelzer, Chem. Ber., 1994, 127, 481-488; (b) F. W. B. Einstein, R. H. Jones, Y. Zhang and D. Sutton, Inorg. Chem., 1988, 27, 1004-1010; (c) C. Hahn, J. Sieler and R. Taube, Polyhedron, 1998, 17, 1183-1193; (d) F. Lorenzini, B. O. Patrick and B. R. James, Inorg. Chim. Acta, 2008, 361, 3199-3204; (e) Y. Wang, B. Zheng, Y. Pan, C. Pan, L. He and K.-W. Huang, Dalton Trans., 2015, 15111-15115; (f) H.-C. Böttcher and P. Mayer, Z. Anorg. Allg. Chem., 2016, 642, 299-301.

6 (a) M. Atanasov, D. Ganyushin, D. A. Pantazis, K. Sivalingam and F. Neese, Inorg. Chem., 2011, 50, 7460-7477; (b) S. K. Singh, J. Eng, M. Atanasov and F. Neese, Coord. Chem. Rev., 2017, 344, 2-25; (c) F. Neese, Wiley Interdiscip. Rev.: Comput. Mol. Sci., 2012, 2, 73-78; (d) F. Neese, Wiley Interdiscip. Rev.: Comput. Mol. Sci., 2018, 8, e1327.

7 R. Núñez, M. Tarrés, A. Ferrer-Ugalde, F. F. de Biani and F. Teixidor, Chem. Rev., 2016, 116, 14307-14378.

8 (a) M.-H. Baik and R. A. Friesner, J. Phys. Chem. A, 2002, 106, 7407-7412; (b) Y. Shimodaira, T. Miura, A. Kudo and H. Kobayashi, J. Chem. Theory Comput., 2007, 3, 789-795; (c) L. Yan, Y. Lu and X. Li, Phys. Chem. Chem. Phys., 2016, 18, 5529-5536.

9 C. A. Jaska, K. Temple, A. J. Lough and I. Manners, Chem. Commun., 2001, 962-963.

10 (a) O. J. Metters, S. R. Flynn, C. K. Dowds, H. A. Sparkes, I. Manners and D. F. Wass, ACS Catal., 2016, 6, 6601-6611; (b) E. M. Titova, E. S. Osipova, A. A. Pavlov, O. A. Filippov, S. V. Safronov, E. S. Shubina and N. V. Belkova, ACS Catal., 2017, 7, 2325-2333; (c) T. M. Maier, S. Sandl, I. G. Shenderovich, A. Jacobi von Wangelin, J. J. Weigand and R. Wolf, Chem. - Eur. J., 2019, 25, 238-245.

11 W. L. F. Armarego and C. L. L. Chai, Purification of Laboratory Chemicals, Butterworth-Heinemann, Oxford, 2009.

12 G. Giordano, R. H. Crabtree, R. M. Heintz, D. Forster and D. E. Morris, Inorg. Synth., 2007, 28, 88-90.

13 CrysAlis Pro: Data Collection and Data Reduction Software Package, Agilent Technologies.

14 G. M. Sheldrick, Acta Crystallogr., Sect. A: Found. Crystallogr., 2008, 64, 112-122.

15 K. Brandenburg and H. Putz, DIAMOND, Crystal Impact GbR, Bonn, Germany, 2006. 